\title{
TAXATION OF FOUND PROPERTY AND OTHER WINDFALLS
}

Eisner v. Macomber dies a slow death.

-Douglas, J., dissenting.*

The question of whether property found unexpectedly is income to the finder within the meaning of the Sixteenth Amendment ${ }^{1}$ and Section 22(a) of the Internal Revenue Code ${ }^{2}$ was discussed in a recent tax service bulletin, ${ }^{3}$ which expressed the opinion that the fair market value of such property is income to its finder. The bulletin recognized that the problem of found property is but one aspect of the larger problem of "windfalls."

The term "windfall" denotes value which is received by a person unexpectedly as a result of good fortune rather than as a result of effort, intelligence, or the venturing of capital. Appreciation in the value of property has occasionally been termed a windfall in the literature. ${ }^{4}$ To the extent that such gain is the result of intelligent risking of capital by the investor, this terminology seems misleading. Only those gains from "an unsought, uncalculated, unexpected, fortuitous rise ... in the value of ... previously existing assets" may appropriately be termed windfalls. In the capital gain field, the law has made no distinction between windfall and other gains. All realized capital gains are considered taxable income under the definition in Eisner v. Macomber: " 'Income may be defined as the gain derived from capital, from labor, or from both combined,' provided it be understood to include profit gained through a sale or conversion of capital assets...." With regard to non-capital gain windfalls, however, the law is less clear. The Internal Revenue Code is silent on the question, and thus far the field has been developed solely through the courts.

* Helvering v. Griffiths, 318 U.S. 371, 404 (1943).

${ }^{3}$ U.S. Const. Amend. 16: "The Congress shall have power to lay and collect taxes on incomes, from whatever source derived, without apportionment among the several States, and without regard to any census or enumeration."

2 Int. Rev. Code $\$ 22(a)$ : " 'Gross income' includes gains, profits, and other income derived from salaries, wages, or compensation for personal services . . of whatever kind and in whatever form paid, or from professions, vocations ... or sales or dealings in property . . . growing out of the ownership or use of or interest in such property; also from interest, rent, dividends, securities, or the transaction of any business carried on for gain or profit, or gains or profits and income derived from any source whatever."

35 CCH 1953 Fed. Tax Rep. I 8730. See Edward J. Dougherty v. Comm'r, 10 T.C.M. 320 (1951), recognizing, but not deciding, question whether found money was income within statute.

4 Tax Institute, Panel Discussion, Capital Gains Taxation (1946): Professor Seltzer: "Another concept of income from which capital gains and losses are reasonably excluded might be termed the prudent consumption concept. This widely held concept distinguishes between regularly recurring income and windfalls on the ground that only the former may be prudently spent." Professor Seltzer, however, does not believe that all capital gains are windfalls. See text at note 5 suprra.

${ }^{5}$ Seltzer, The Nature and Tax Treatment of Capital Gains and Losses 53 (1951).

- 252 U.S. 189, 207 (1920). In Merchant's Loan and Trust Co. v. Smietanka, 255 U.S. 509 (1921), it was held that the word "income" in the 16th Amendment included a gain from a single sale as well as profits from sales by one engaged in the business of buying and selling. 


\section{ARE WINDFALLS EXCLUDED FROM INCOME BY THE "MACOMEER" DEFINITION?}

The first case on the taxation of non-capital gain windfalls was Central Railroad Company v. Commissioner ${ }^{7}$ decided in 1935 by the Court of Appeals for the Third Circuit. The Central Railroad case held that a recovery of profits made by a corporate officer who had engaged in surreptitious business operations adverse to the interests of the corporation did not constitute income to the corporation. The court based its decision on an extremely literal application of the Eisner v. Macomber definition of income. The court said: "[T]he value of the property ... cannot be traced to either capital or labor. ... [W] [Wat it [the corporation] received was in the nature of a 'windfall.' It was a penalty imposed by the law on a faithless fiduciary, a gain granted gratuitously because of the necessity of keeping persons in positions of trust beyond the temptation of double dealing. ... Moreover, the settlement was not based on a suit by the taxpayer to recover profits of which it had been deprived."8

In 1941, Arcadia Refining Company v. Commissioner ${ }^{9}$ was decided by the Fifth Circuit. Here, money was received in settlement of a lawsuit against an officer who had appropriated assets of his corporation to finance a profitable competing enterprise. The proceeds of settlement were held taxable income to the corporation, with the exception of that part allocable to the conversion of assets, which part represented only a return of capital. In reaching this result, the court in the Arcadia case may not have treated the situation as involving a windfall. The Board of Tax Appeals below (now the Tax Court) had found that the recovery was of "profits" taxable as income and the reviewing court simply decided that the finding of the Board was fully supported by the evidence and should not be disturbed. Yet the case does not indicate whose profits were being recovered. If the profits were actually earned by the corporation and kept by the officer as agent in breach of his fiduciary duty, there would be little question that they would be taxable income to the corporation. If the profits were actually earned by the officer and were awarded to the corporation solely to punish the officer for his breach of duty in earning profits, the recovery would be a windfall, and holding it taxable conflicts with the Central Railroad case. If the profits were actually earned by the officer but awarded to the corporation

779 F. $2 d 697$ (C.A. 3d, 1935).

8 Ibid., at 699 . While the corporation's suit was not framed as an action to recover lost profits, it may be that taxpayer's dealings with its officer, in the form of leases and contracts with a corporation controlled by the officer, reduced taxpayer's profits below the level they might have reached absent such dealings. To the extent of such loss of profits, taxpayer's recovery would not be a true windfall and would be taxable as ordinary income. In addition, the fact that taxpayer, by suing, expended some "effort" in gaining its recovery might take the case out of the "windfall" category as generally understogd. But the tendency of the courts is to disregard the lawsuit as such as the "cause" of the recovery and to focus on the underlying situation which prompts the relief. Cases involving deductibility of legal expenses similarly turn on the nature of the underlying activity. Cf. Lykes v. United States, 343 U.S. 118, 123 (1952), noted in 20 Univ. Chi. L. Rev. 247 (1953).

? 118 F. 2d 1010 (C.A. 5th, 1941). 
because they should have been profits of the corporation in that the opportunity to earn them was a corporate opportunity which the officer wrongfully usurped, then it would seem their recovery would be income under the common notion that damages awarded in lieu of income are income. ${ }^{10}$ The fact that assets of the corporation were used to produce the income in the Arcadia case, and not in the Central Railroad case, seems to distinguish the cases and strengthens the corporate opportunity analysis of the former. Alternatively, it could be argued that the recovery in the Arcadia case may be considered to have been of profits derived from the capital of the corporation itself since its assets were used in producing the profit. Thus the profit would literally fall within the Eisner $v$. Macomber definition of taxable income. In any event, the Arcadia case does not consider the fund involved explicitly from a windfall viewpoint, nor does it even cite the Central Railroad case. Moreover, the Arcadia case itself has not been cited in subsequent windfall opinions.

Between the decisions in the Central Railroad case and the Arcadia case, a 1940 decision by the Board of Tax Appeals, Highland Farms Corporation, ${ }^{11}$ held punitive damages awarded in an action for slander of title and willful interference in the conduct of taxpayer's business not to be income. The reasoning was that these damages were awarded neither for loss of capital nor for loss of profits, but as a penalty, and Central Railroad had already declared that penalties did not fall within the definition of taxable income set forth in Eisner v. Macomber. In August 1952, this reasoning was reaffirmed by the Tax Court in Glenshane Glass Company, ${ }^{12}$ involving the punitive damage portion of a tripledamage antitrust settlement. The Tax Court cited Central Railroad and Highland Farms and declared its adherence to the "rule of long standing that has never been questioned in any court" that sums received in settlement of punitive damage claims do not constitute taxable income. ${ }^{13}$

In November 1952, two and one-half months after the Glenshaw case, a decision by the Court of Claims, Park \& Tilford Distillers Corporation v. United States, ${ }^{14}$ rejected Central Railroad and Highland Farms insofar as they relied upon the definition of income in Eisner v. Macomber; the Glenshare case was not cited. Park \& Tilford held that insider's profits turned over to taxpayer cor-

${ }^{10}$ Plumb, Income Tax on Gains and Losses in Litigation, 25 Cornell Ĺ.Q. 221 (1940).

${ }^{11} 42$ B.T.A. 1314 (1940).

${ }_{12}$ CCH Tax Ct. Rep. ๆ 19,146, 18 T.C. No. 108 (1952).

13 Whether defendant in an antitrust suit can deduct the triple damage payment from his taxable income either as a loss or an expense raises the question of whether Congress's purpose in providing triple damages was to induce injured parties to sue and thereby aid in the enforcement of the antitrust laws, or simply to punish the guilty party. However, even if the congressional intent were primarily to offer plaintiffs an inducement to sue, it would not automatically follow that defendants should be granted relief from the consequence of their misdeeds in the form of tax reduction. Cf. Comm'r v. Longhorn Portland Cement Co., $148 \mathrm{~F}$. $2 d 276$ (C.A. 5th, 1945), which held that amounts paid in compromise of state antitrust suit are not deductible as business expenses: Accord: Universal Atlas Cement Co. v. Comm'r, 171 F. 2d 294 (C.A. 2d, 1948).

14107 F. Supp. 941 (Ct. Cl., 1952). 
poration in accordance with the provisions of the Securities Exchange Act ${ }^{15}$ were income to the corporation under the "any source whatever" phrase of Section 22(a). The definitional language in Eisner v. Macomber was limited to the special problem of whether a realization of gain had occurred on the declaration of a stock dividend, a problem not involved in Park \& Tilford. The court said:

It is not, and we think could not rationally be, suggested that Congress lacks the power to tax windfalls as income... . A windfall may, of course, be a gift, and thus expressly exempt from income tax. But if, as in the instant case, the windfall is clearly not a gift, but a payment required by a statute, ... we do not see how its exemption could be reconciled with the reiterated statements that Congress intended, by Section 22(a), to tax income to the extent of its constitutional power. ${ }^{16}$

General American Investors Company, ${ }^{17}$ decided by the Tax Court in December 1952, shortly after Park \& Tilford, followed the Court of Claims decision in that case by holding that insider's profits recovered by a corporation were taxable income to the corporation. The court distinguished Highland Farms and Glenshaw simply on the ground that these two cases involved punitive damages. ${ }^{18}$ The court did not make clear, however, why the difference in fact between punitive damages and insider's profits should lead to a different tax result.

A concurring opinion quoted the peculiar language of the Securities Exchange Act, ${ }^{19}$ which provides that insider's profits shall "inure to and be recoverable by" the corporation, and then concluded, "Thus the profits here in question were income of the petitioner within ...22(a) since they were 'profit' either from 'sales or dealings in property ${ }^{* * *}$ growing out of ownership of $* * *$ or interest in such property' or 'from any source whatever.' " The concurring judge, however, does not make explicit the logic by which he moves from the language of the Securities Exchange Act to the conclusion of taxability. The words of the Act might be used to support any one of three possible constructions: (1) profits will be considered as earned by the officer, but the corporation shall have a legal right to recover them; (2) although the profits will be considered earned by the officer, they become the property of the corporation from

${ }^{15}$ Securities Exchange Act of 1934, \& 16(b), 48 Stat. 896 (1934), 15 U.S.C.A. § 78p(b) (1951).

16107 F. Supp. at $943-44$.

${ }^{17} \mathrm{CCH}$ Tax Ct. Rep. I 19,372, 19 T.C. No. 73 (1952).

${ }^{18}$ The taxpayer in Park \& Tilford urged that the payment of insider's profits was a penalty imposed upon the insider. The court, however, said that this question would be of importance only where the insider sought to deduct the payment from his taxable income as a loss or an expense. In this event, the deductibility might depend upon whether the policy of the law is to penalize the insider for doing acts which the law wishes to discourage, or whether the insider is to be permitted to bolster the market for the securities of his corporation but only prevented from retaining the gains. The Tax Court has held that the insider is not entitled to the deduction. William F. Davis, Jr., 17 T.C. 549 (1952).

19 Securities Exchange Act of 1934, $\S 16$ (b), 48 Stat. 896 (1934), 15 U.S.C.A. $\S 78$ p(b). (1951). 
the moment they are earned; or (3) the corporation itself will be considered the earner. The first construction simply raises the windfall question, and appears to be the situation the majority was assuming. The second construction will not necessarily result in a tax to the corporation. In other cases, such as assignment by a wage-earner of his right to future wages, the income is taxable to the earner irrespective of whether the legal title to the income ever rests in him even momentarily. ${ }^{20}$ The third construction would seem to be the only one on which the concurring opinion could rely and yet it seems a strained interpretation of the words "inure to and become recoverable by." Further, as a matter of fact, the effort, and thus the act of "earning," was all on the part of the insider, not the corporation.

In the most recent windfall case, William Goldman Theaters, Inc., ${ }^{21}$ decided in January 1953, the Tax Court relied on the Glenshaw, Highland Farms, and Central Railroad cases in holding that the two-thirds of a triple-damage judgment in an antitrust suit which represented punitive damages was not income. Park \& Tilford was not mentioned. In distinguishing the General American case, the court highlighted, as did the majority in General American, the fact that punitive damages were not insider's profits. The court also referred to the same wording of the insider's profit statute which had been relied on by the concurring opinion in General American.

Thus Park \& Tilford refused to extend the vitality of the Eisner v. Macomber definition of taxable income beyond the facts of that case. The Central Railroad, Highland Farms, and Glenshaw cases used the definition to determine taxability of windfalls. In distinguishing these earlier cases rather than overruling them, the Tax Court, in General American and William Goldman Theaters, has created two classes of windfalls: penalties and insider's profits. If a case of found property arises, the court will be faced with the problem of whether such property is more like the nontaxable penalty or the taxable recovery under the Securities Exchange Act.

Perhaps a more appropriate interpretation of Section 22(a) would be to hold that all windfalls, including penalties, are taxable income under its sweeping language. A Treasury Regulation interpreting Section 22(a), which provides that income means "all wealth which flows in to the taxpayer other than as a mere return of capital, ${ }^{, 22}$ would seem to suggest this result. Insofar as the policy of Section 22(a) is to impose similar tax burdens on persons in similar circumstances, there is no basis for distinguishing value received as a windfall and, for example, value received as a salary. By the same reasoning, there is no basis for distinguishing between an award of value labelled "penalty" and one labelled

${ }^{20}$ Lucas v. Earl, 281 U.S. 111 (1930). See also Helvering v. Horst, 311 U.S. 112 (1940) (taxing donor of bond interest coupon on interest when received by donee-owner).

${ }^{21}$ CCH Tax Ct. Rep. 『 19,401, 19 T.C. No. 79 (1953).

22 Treas. Reg. 111, \& 29.21-1. 
"insider's profits." ${ }_{23}$ To the extent that the income tax is progressive, and to the extent that it is desirable to have the burden of the progression fall upon the people with the greatest addition to their economic power within the given period, the same reasoning would apply.

It may be thought that a person who receives value only sporadically is not in the same circumstance as a person who receives the identical value from a recurring source. The argument is that a prudent man will regard sporadic receipts differently and will not treat them as available for ordinary consumption. ${ }^{24}$ From this it is concluded that the receipts should be taxed at a lower rate or not taxed at all. But it may be concluded with equal logic that the receipts should be taxed at an even higher rate, for the recipient does not depend upon them for subsistence. In any case, the Internal Revenue Code, by and large, has rejected the sporadic-receipt argument, except that those gains falling within the technical term "capital gain" are taxed at a bargain rate. In addition, no distinction is made between the sporadic income of a prize fighter and the stable income of a college professor. ${ }^{25}$

\section{PROBLEMS OF BASIS IF WINDFALLS ARE EXCLUDED FROM INCOME}

If it is assumed that windfalls are to be excluded from taxable income by the definition of income in Eisner v. Macomber, one resulting basis problem may be suggested by the following example: On January 1 , A finds $\$ 5,000$ cash and $B$ finds property with a fair market value of $\$ 5,000$. A immediately spends his $\$ 5,000$ cash for consumption purposes; B sells the property and spends the $\$ 5,000$ proceeds for consumption purposes. B's resulting position is identical with that of A. A pays no tax. However, B can avoid a tax only if he is to be assigned a basis of $\$ 5,000$ for the found property. It is not clear whether the Internal Revenue Code, as now interpreted, will permit B to take such a basis. The Code defines basis as cost. ${ }^{26}$ Since the found property does not appear to have "cost" B anything, it would seem that his basis for the property would be zero. This would result in a taxable gain of $\$ 5,000$ on the sale of the property.

${ }^{23} \mathrm{Cf}$. the concept of income in Simons, Personal Income Taxation (1938), as including "(1) the market value of rights exercised in consumption, and (2) the change in the value of the store of property rights between the beginning and the end of the period in question." Ibid., at 50 . See text at note 22 supra.

24 Seltzer, op. cit. supra note 5 , at 25 .

${ }^{25}$ It is sometimes suggested that receipts not includible in the concept "national income" should not be taxed to the recipient. National income "denotes, broadly, a measure of the net results of economic activity in a community during a period of time." Simons, op. cit. supra note 23 , at 45 . A windfall, being only a transfer of the result of economic activity rather than an addition to the result of such activity, is not a part of national income. However, Simons himself does not believe that the concept of national income has any place in the income tax. Ibid., at 47.

${ }^{26}$ Int. Rev. Code $\S 113(a):$ "The basis of property shall be the cost of such property; except that ..." and then follows 2 list of specific exceptions which are not applicable here. Section 113(b)(2) provides that a substitute basis shall be used in certain specific cases again not applicable. 
A possible argument that would permit an escape from the use of the zero basis is suggested by an analysis of the rule that one who pays an income tax upon the receipt of property is entitled to a basis equal to the amount included in his income. ${ }^{27}$ Two rationales have been suggested for this rule: (1) The recipient has really incurred a cost-by the rendering of services, the surrender of debts due him, or the like-equal to the value of what he has received. This line of reasoning, however, does not explain the fact that the recipient of a dividend in kind is allowed a basis although he has apparently incurred no cost. $^{28}$ (2) The recipient has been taxed on the value of the property to the extent that it has been included in income, and the basis given him is designed to prevent a second tax on the same value when the property is sold. This rationale, however, does not adequately explain those cases in which the fair market value of property at the time of receipt was improperly not reported as income, and yet the property still received as a basis such fair market value. ${ }^{29}$

The first rationale will not aid the windfall finder of property, since he incurs no cost. The second rationale, however, is an exception to the cost rule. It may be argued that, if the law has a policy against taxing twice that which is income, it ought also to have a policy against taxing once that which is not income at all. It would seem that were found property not income if never sold, it should not become income when it is sold. ${ }^{30}$ To hold otherwise would discriminate against $A$, the finder of cash in the above example, as opposed to $B$, the finder of other property which is subsequently sold for cash.

In Deiroit Edison Company v. Commissioner, ${ }^{31}$ the Supreme Court held that assets constructed with money furnished by customers had a basis of zero for

${ }^{27}$ Treas. Reg. 111, $\S 29.22$ (a)-1, provides that "if property is transferred by a corporation to a shareholder, for an amount less than its fair market value ... such shareholder shall include in gross income the difference between the amount paid for the property and the amount of its fair market value. ... In computing the gain or loss from the subsequent sale of such property its basis shall be the amount paid for the property, increased by the amount of such difference included in gross income." The regulation provides a like increase in the basis for property transferred by an employer to an employee for an amount less than its fair market value. See also Surrey and Warren, Federal Income Taxation 466-67 (1950).

${ }^{28}$ See Greenbaum, The Basis of Property Shall be the Cost of Such Property: How is the Cost Defined?, 3 Tax L. Rev. 351 (1948).

${ }^{29}$ See, e.g., Helvering v. Salvage, 297 U.S. 106 (1935); Robbins v. United States, 21 F. Supp. 403 (Ct. Cl., 1937). But see Timken v. Comm'r, 141 F. 2d 625 (C.A. 6th, 1944), and Continental Oil Co. v. Jones, 177 F. 2d 508 (C.A. 10th, 1949), disallowing the higher basis where the receipt of the property was improperly excluded from income.

${ }^{30}$ It was once the law that the basis on sale for nontaxable stock dividends was zero. Helvering v. Gowran, 302 U.S. 238 (1937). Now the basis for the old stock is apportioned between the old and the new. Int. Rev. Code $\$ 113(\mathrm{a})(19)$. The latter result seems more appropriate. Since a nontaxable stock dividend is really only the spreading out of an old investment, presumably the value of each share after the dividend will fall in proportion to the amount of the new issue. Therefore, the old system would produce false gains upon the sale of the new stock and false losses upon the sale of the old, whereas the present system produces neither false gains nor losses.

"11 319 U.S. 98 (1943). 
purposes of depreciation. ${ }^{32}$ The court appears to advance two arguments for this result. First, since the property was paid for by customer funds, the company incurred no cost and was therefore not entitled to a basis under the cost rule. Second, the customer funds, while they "were to the customer the price of the service," were not taxed as income to the company, ${ }^{33}$ and therefore did not entitle the company to a basis under the inclusion-in-income rule. ${ }^{34} \mathrm{It}$ could be argued that the Detroit Edison case rests its holding of zero basis mainly on the ground that, while neither the money nor the property was included in income at the time it was received, it should be included in income at some time. If it is decided that windfall found property is not income at all, the Detroit Edison case does not necessarily preclude the finding of a positive basis for such property.

If found property, not taxed as income to the finder, is to have a positive basis when sold, the next basis problem is whether the basis should be the fair market value of the property at the time it is found, at the time it is sold, or at the time the statute of limitations has run against the loser. Returning to the example discussed above, assume that $B$, instead of selling the property on January 1 , retains it until July 1 , and that the statute of limitations bars the loser's claim on March 1, by which date the market value of the property has risen to $\$ 7,000$. B sells the property July 1 for $\$ 8,000$. Clearly, at least the final $\$ 1,000$ of appreciation should be taxed to $B$, since that appreciation was in the value of an asset owned by $B$ and was realized by sale. The additional appreciation of $\$ 2,000$, however, took place while title to the property was vested in the loser of the property. It could be argued that $B$ therefore takes as his basis $\$ 7,000$, the value of the property at the time title vests in him, and that the $\$ 2,000$ appreciation between January 1 and March 1 is not income to him. But if B's basis is not the value of the property when found, then the appreciation in value during the running of the statute of limitations would escape tax altogether.

\section{TREATMENT OF WINDFAILS IF NOT EXCLUDED FROM INCOME}

If it is assumed that found property windfalls are not to be excluded from taxable income by the definition of income in Eisner v. Macomber, the questions of when the tax is to be imposed, what basis is to be assigned the windfall property, and what tax consequences will result from return of the property to its owner remain to be considered. ${ }^{35}$

32 In this area the basis for depreciation is the same as the basis for gain or loss on sale. Int. Rev. Code \& 114(a).

35 The Court said that these receipts "had not been taxed as income presumably because it had been thought to be prescribed by this Court's decision in Edwards v. Cuba Railroad Company holding that ... a government subsidy to induce railroad construction was not income." Detroit Edison Co. v. Comm'r, 319 U.S. 98, 103 (1943).

${ }^{34}$ See text at note 27.

35 The realization doctrine prevents taxation of appreciation in the value of an existing property interest. See Roehner and Roehner, Realization: Administrative Convenience or 
It may be possible to impose the tax either when the property is found, when the finder claims it as of right, or when the statute of limitations has run against the loser. Once the statute has run, it appears clear that the finder should be taxed if he has not been taxed before. But it may not be necessary to wait for the expiration of the statute if the finder may be considered to hold the property under a "claim of right and without restriction as to its disposition." ${ }^{36} \mathrm{Com}$ missioner $v$. Wilcox ${ }^{37}$ added to the claim-of-right doctrine the requirement of "the absence of a definite, unconditional obligation to repay or return that which would otherwise constitute a gain. Without some bona fide legal or equitable claim, even though it be contingent or contested in nature, the taxpayer cannot be said to have received any gain or profit within section 22(a)."38 This would mean, of course, that a finder could not be taxed until the statute of limitations had extinguished his obligation to return. Rutkin v. United States, ${ }^{39}$ although nominally distinguishing the Wilcox case, ${ }^{40}$ appears to have erased this requirement, opening the door once more to taxation of windfalls prior to the running of the statute. ${ }^{41}$

Constitutional Requirement, 8 Tax L. Rev. 173 (1953). The receipt of windfall found property, however, constitutes a new property interest for the finder rather than appreciation in the value of a previously existing interest.

If a natural resource, such as oil, is located as a result of the expenditure of capital and labor in prospecting and drilling, there may be a question whether such nonwindfall finding is a realization of value. If the oil rights in the land or the land on which the oil is found were owned by the finder prior to discovery, he has apparently realized nothing by his finding; he has merely engaged in activity which appreciated the value of an asset which he already owned. It might be argued that the act of finding and preparing the oil for market so changes its nature that a realization of its appreciation in value occurs. But the extraction of oil appears indistinguishable from the ordinary manufacturing process, and the general rule is that products of manufacture are not income until sold.

${ }^{36}$ The "claim of right" doctrine was established by Justice Brandeis in North American Oil Consolidated v. Burnet, 286 U.S. 417 (1932): "If a taxpayer receives earnings under a claim of right and without restriction as to its disposition, he has received income which he is required to return, even though it may still be claimed that he is not entitled to retain the money, and even though he may still be adjudged liable to restore its equivalent." Ibid., at 424.

${ }^{37} 327$ U.S. 404 (1946).

${ }^{38}$ Ibid., at 408.

${ }^{39} 343$ U.S. 130 (1952).

${ }^{40}$ The Wilcox case involved embezzlement while the Rutkin case involved extortion. Although the Court in the Rutkin case specifically said that it did not reach the facts in the Wilcox case, it has been suggested that the authority of the Wilcox case has been destroyed. See, e.g., The Supreme Court, 1951 Term, 66 Harv. L. Rev. 89, 173 (1952). A possible distinction may be found in the fact that an embezzler never acquires legal title to the money, whereas an extortioner does acquire legal title, subject only to an equitable right in the victim to get the money back.

11 If the tax is put off until the full statute of limitations has run or until the finder has unambiguously appropriated the property, the finder is being given a "free ride" in terms of speculating in fluctuations of value of the property during the statutory period. If the law were to swing to the opposite extreme and declare found property income the moment it is found, the finder would be faced with the burden of paying a tax on property which he might be diligently attempting to return to the true owner. Presumably, the value of the property for income tax purposes and the beginning of the holding period would be determined by the date upon which the property became income to the finder. 
The second problem in dealing with the taxation of windfall property is what basis the property is to be assigned on sale. Assuming that the finder has already been taxed on the property as income, he would take as his basis for the property the value given it when it was included in his income. ${ }^{42}$ If the finder has improperly failed to pay an income tax on the found property, the cases are unclear as to whether he may be forced to take a basis of zero on sale. ${ }^{43}$

Whenever a finder who has paid a tax on windfall found property returns it to its owner, the question arises whether an adjustment will be made either in the form of a refund for the year the tax was paid or as a deduction for the year in which the property was returned. In the 1947 case of Gargaro v. United States, ${ }^{44}$ where taxpayer, entitled to a percentage of corporate net income, figured the income incorrectly because the government later renegotiated a contract with the corporation, the Court of Claims held that the prior return should be amended because the money was received under a mistake of fact and there "really" was an obligation to return. While the obligation was unknown, the Wilcox case had decided that if there was an unconditional obligation, the item was not income. Two years later, however, in Haberkorn v. United States, ${ }^{45}$ the Court of Appeals for the Fourth Circuit reached the opposite result, citing North American Oil Consolidated v. Burnet, ${ }^{46}$ which it claimed was not overruled by the Wilcox case. In 1951, in United States v. Lewis, ${ }^{47}$ taxpayer had included a bonus in his gross income when he received it, but was later forced by subsequent litigation in a state court to give back a portion of the bonus. The Supreme Court held taxpayer was not entitled to exclude that portion of the bonus from his earlier income tax return. "Nothing in this language [North American case] permits an exception [to the claim of right notion] merely because a taxpayer is 'mistaken' as to the validity of his claim." 48

If the person who returns found property previously taxed is to be denied a refund, he may attempt to claim a deduction for the year in which the property was returned. While it is difficult to point to any provisions of the Internal

2 See text at note 27 supra.

${ }^{43}$ See text at note 29 supra; bul cf. text at note 34 supra.

473 F. Supp. 973 (Ct. Cl., 1947). See also Greenwald v. United States, 57 F. Supp. 569 (Ct. Cl., 1944).

15173 F. 2d 587 (C.A. 6th, 1949).

16286 U.S. 417 (1932).

17340 U.S. 590 (1951).

18 Ibid., at 591. In Healy v. Comm'r and Comm'r v. Smith, 73 S. Ct. 671 (U.S., 1953), taxpayers had received salaries from their corporate employers which they reported as income. Later, part of each salary was held excessive and each taxpayer became liable as transferee for the unpaid taxes of his employer corporation. The Supreme Court held that the past returns for the years in which taxpayers had reported their salaries could not be reopened. The Commissioner conceded, however, that the taxpayers were entitled to a deduction for a loss in the year of repayment of the amount earlier included in income. 
Revenue Code that would permit such a result, ${ }^{49}$ it seems rough justice to allow the deduction..$^{50}$

49 For deductions from gross income, see Int. Rev. Code $\$ 23$.

${ }^{50}$ See, generally, on this problem, Mistake and the Claim of Right Doctrine, 46 Ill. L. Rev. 497 (1951). See also note 48 supra.

After this comment went to press, the Bureau of Internal Revenue made the following ruling: "Gross income: Treasure-trove.-The finder of buried treasure is in receipt of taxable income. The amount of the income is to be measured by its value in United States currency for the taxable year in which it is reduced to undisputed possession." Rev. Ruling 61, 1953 Int. Rev. Bull. No. 9, at 2, 5 CCH 1953 Fed. Tax Rep. \6171. The ruling appears to deal only with property found as the result of labor and therefore taxable income even within the definition in Eisner v. Macomber. The ruling does, however, make more certain that this result would, in fact, be reached and, in addition, appears to answer the problem of when such property is taxable income. 